\title{
Survey of acute exacerbation after nonpulmonary surgery in patients with interstitial pneumonia
}

\author{
Miho Hamada, Ryuichi Wakata, Misaki Saito Sato and Toshiyuki Mizota *i]
}

\section{To the Editor:}

Acute exacerbation (AE) of interstitial pneumonia (IP) is described as an acute respiratory deterioration accompanied by newly developed bilateral groundglass opacity and/or consolidation identified on chest radiographs or computed tomography $(\mathrm{CT})$ scans. It occurs in $9.3-15.8 \%$ of patients with IP undergoing pulmonary surgery and has a high fatality rate [1-3]. In contrast, limited data exists on the incidence of $\mathrm{AE}$ after nonpulmonary surgery; only three reports have been published so far, and the reported incidence deviates from 1.4 to $6.3 \%$ [4-6]. One of these reports compared the incidences of $\mathrm{AE}$ after pulmonary and nonpulmonary surgeries but noted no significant difference [4]. In this study, we examined the incidence of $\mathrm{AE}$ within 30 days after nonpulmonary surgery in patients with IP.

Figure 1 shows the flow diagram of this study. We included 220 patients with IP undergoing nonpulmonary surgery under general anesthesia at Kyoto University Hospital between 2008 and 2017. Patients with IP were identified by screening using the 10th revision of the International Statistical Classification of Diseases and Related Health Problems (ICD-10) diagnosis codes, followed by a review of chest CT reports. The diagnosis of $\mathrm{AE}$ was made based on the same criteria used in previous studies: (1) new bilateral groundglass opacity/consolidation identified on chest CT, (2) acute worsening or development of dyspnea noted in the medical records, and (3) exclusion of heart failure, excessive fluid infusion, or lung infection as causes [4-6].
Table 1 shows the characteristics and operative variables of patients included in this study. No patients who underwent nonpulmonary surgery reported $\mathrm{AE}$ within 30 days after surgery; two patients presented with new infiltrative shadows on chest CT within 30 days after surgery, both of which were unilateral and caused by lung infection. The incidence of $\mathrm{AE}$ after nonpulmonary surgery was estimated to be $1.5 \%$ (95\% confidence interval: $0.9-2.4 \%$ ), when the result of this study was integrated with those of previous studies [4-6]. On the other hand, one of the 32 patients with IP undergoing pulmonary surgery had $\mathrm{AE}$ within 30 days after surgery.

The incidence of $\mathrm{AE}$ after nonpulmonary surgery estimated in this study tended to be lower than that reported in previous studies, possibly because fewer patients had known risk factors for postoperative $\mathrm{AE}$, such as usual IP pattern, AE history, and a high Creactive protein level (Table 1) [5]. The data of this study could reinforce the hypothesis that postoperative $\mathrm{AE}$ is less common in patients undergoing nonpulmonary surgery than those undergoing pulmonary surgery, although the previous study did not find any significant difference in the incidence of postoperative AE between pulmonary and nonpulmonary surgeries [4].

Due to various limitations, further validation of our findings is warranted. For example, few patients in this study had known AE risk factors, which may be due to the exclusion of high-risk patients from surgical treatment. Our study and all other previous studies have been carried out in Japan, thereby limiting the generalization of results to other settings.

\footnotetext{
* Correspondence: mizota@kuhp.kyoto-u.ac.jp

Department of Anesthesia, Kyoto University Hospital, 54

Shogoin-Kawahara-Cho, Sakyo-Ku, Kyoto 606-8507, Japan
}

Springer Open (c) The Author(s). 2021 Open Access This article is licensed under a Creative Commons Attribution 4.0 International License which permits use, sharing, adaptation, distribution and reproduction in any medium or format, as long as you give appropriate credit to the original author(s) and the source, provide a link to the Creative Commons licence, and indicate if changes were made. The images or other third party material in this article are included in the article's Creative Commons licence, unless indicated otherwise in a credit line to the material. If material is not included in the article's Creative Commons licence and your intended use is not permitted by statutory regulation or exceeds the permitted use, you will need to obtain permission directly from the copyright holder. To view a copy of this licence, visit http://creativecommons.org/licenses/by/4.0/. 


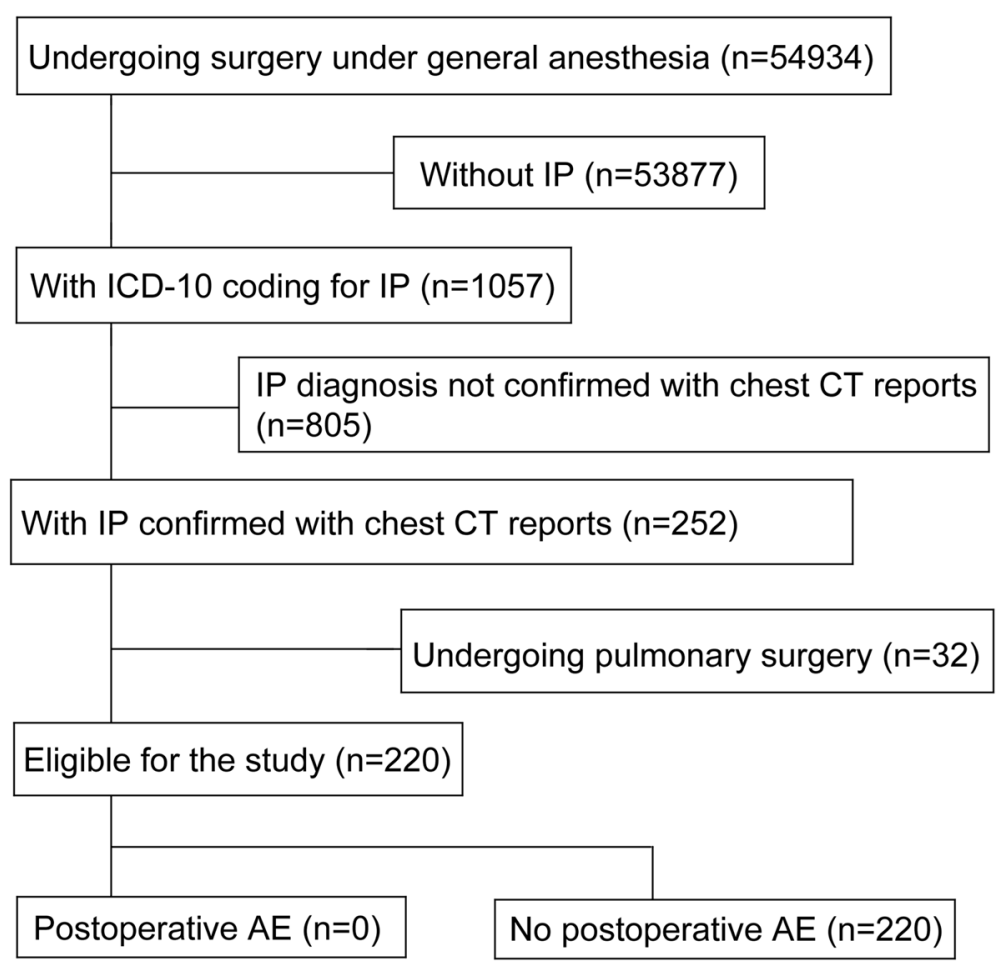

Fig. 1 Flow diagram of the study participants. IP interstitial pneumonia, ICD International Classification of Disease, CT computed tomography, AE acute exacerbation

Table 1 Characteristics and operative variables of patients included in this study who underwent nonpulmonary and pulmonary surgeries

\begin{tabular}{lll}
\hline Characteristics & Nonpulmonary surgeries $(\boldsymbol{n}=\mathbf{2 2 0})$ & Pulmonary surgeries $(\boldsymbol{n}=\mathbf{3 2})$ \\
\hline Age (years) & $70[62-77]$ & $61[43-74.5]$ \\
Males & $114(52 \%)$ & $26(81.3 \%)$ \\
Body mass index $\left(\mathrm{kg} / \mathrm{m}^{2}\right)$ & $21.7[19.0-23.9]$ & $22.3[18.2-24.1]$ \\
Ever smoker & $74(33.6 \%)$ & $16(50 \%)$ \\
Past acute exacerbation & $1(0.5 \%)$ & $0(0 \%)$ \\
KL-6 (U/mL) & $481[319-778]$ & $519[336-789.5]$ \\
LDH (U/L) & $212[180-251]$ & $211[184.5-231.5]$ \\
CRP (mg/dL) & $0.3[0.1-1.6]$ & $0.2[0.1-0.7]$ \\
Usual interstitial pneumonia pattern & $26(11.8 \%)$ & $2(6.3 \%)$ \\
\%VC (\%) & $84.5[71.4-95.6]$ & $96.5[89.2-99.0]$ \\
FEV1/FVC (\%) & $94.8[91.9-101.5]$ & $96.1[93.9-100.2]$ \\
\%DLCO (\%) & $62.0[44.1-81.2]$ & $67.3[62.5-78.5]$ \\
ASA-PS (1/2/3/4/missing) & $6 / 119 / 60 / 9 / 23$ & $2 / 15 / 10 / 4 / 1$ \\
Emergency surgery & $31(14.1 \%)$ & $15(46.9 \%)$ \\
Duration of anesthesia (min) & $209.5[139.5-349.0]$ & $266[167.5-381]$ \\
Blood loss (mL) & $50[0-214]$ & $19[0-430]$ \\
\hline
\end{tabular}

Continuous variables were presented as medians [interquartile range]. Categorical variables were presented as numbers (percentage). $K L-6 \mathrm{Klebs}$ von den Lungen6, $L D H$ lactate dehydrogenase, CRP C-reactive protein, VC vital capacity, FEV1/FVC forced expiratory volume in 1 s/forced vital capacity, DLCO diffusing capacity for carbon monoxide, ASA-PS American Society of Anesthesiologists Physical Status Classification 


\section{Abbreviations}

AE: Acute exacerbation; IP: Interstitial pneumonia; CT: Computed tomography; ICD-10: International Statistical Classification of Diseases and Related Health Problems - 10th revision

\section{Acknowledgements}

We would like to thank Enago (www.enago.jp) for the English language review.

\section{Authors' contributions}

RW and TM conceptualized and designed the study. MH, RW, and MSS collected the data. MH, RW, and TM performed the statistical analysis. $\mathrm{MH}$ and MSS drafted the manuscript. RW and TM critically revised the manuscript. The authors approved the final manuscript.

\section{Funding}

This work was supported by the JSPS KAKENHI (grant number 20K09242; TM, principal investigator)

\section{Availability of data and materials}

The datasets used and analyzed in this study are available from the corresponding author on a reasonable request.

\section{Declarations}

Ethics approval and consent to participate

This study was approved by the ethics committee of Kyoto University Hospital (approval number: R2647), and the requirement for informed consent was waived.

\section{Consent for publication}

Not applicable.

\section{Competing interests}

The authors declare that they have no competing interests.

Received: 7 January 2021 Revised: 20 March 2021

Accepted: 29 March 2021 Published online: 01 April 2021

\section{References}

1. Chida M, Kobayashi S, Karube Y, Hayama M, Tamura M, Ishihama H, et al. Incidence of acute exacerbation of interstitial pneumonia in operated lung cancer: institutional report and review. Ann Thorac Cardiovasc Surg. 2012; 18(4):314-7. https://doi.org/10.5761/atcs.0a.11.01839.

2. Sato T, Teramukai S, Kondo H, Watanabe A, Ebina M, Kishi K, et al. Impact and predictors of acute exacerbation of interstitial lung diseases after pulmonary resection for lung cancer. J Thorac Cardiovasc Surg. 2014;147(5): 1604-11.e3.

3. Maniwa T, Kondo H, Mori K, Sato T, Teramukai S, Ebina M, et al. Outcomes in surgically managed non-small-cell lung cancer patients with evidence of interstitial pneumonia identified on preoperative radiology or incidentally on postoperative histology. Interact Cardiovasc Thorac Surg. 2015;20(5):6416. https://doi.org/10.1093/icvts/ivv021.

4. Miyamura T, Sakamoto N, Kakugawa T, Okuno D, Yura H, Nakashima S, et al. Postoperative acute exacerbation of interstitial pneumonia in pulmonary and non-pulmonary surgery: a retrospective study. Respir Res. 2019;20(1):154. https://doi.org/10.1186/s12931-019-1128-5.

5. Takao S, Masuda T, Yamaguchi K, Sakamoto S, Horimasu Y, Nakashima T, et al. High preoperative C-reactive protein level is a risk factor for acute exacerbation of interstitial lung disease after non-pulmonary surgery. Medicine (Baltimore). 2019;98(5):e14296. https://doi.org/10.1097/MD. 0000000000014296.

6. Hosoki K, Mikami Y, Urushiyama H, Souma K, Kawamura G, Uchida K, et al. Predictors of postoperative acute exacerbation of interstitial lung disease: a case-control study. BMJ Open Respir Res. 2020;7(1):e000634. https://doi.org/1 0.1136/bmjresp-2020-000634

\section{Publisher's Note}

Springer Nature remains neutral with regard to jurisdictional claims in published maps and institutional affiliations.

\section{Submit your manuscript to a SpringerOpen ${ }^{\circ}$ journal and benefit from:}

- Convenient online submission

- Rigorous peer review

- Open access: articles freely available online

- High visibility within the field

- Retaining the copyright to your article

Submit your next manuscript at $\boldsymbol{\nabla}$ springeropen.com 